\title{
Mrgprd Enhances Excitability in Specific Populations of Cutaneous Murine Polymodal Nociceptors
}

\author{
Kristofer K. Rau, ${ }^{1}$ Sabrina L. Mcllwrath, ${ }^{1}$ Hong Wang, ${ }^{2}$ Jeffrey J. Lawson, ${ }^{1}$ Michael P. Jankowski, ${ }^{1}$ Mark J. Zylka, ${ }^{2}$ \\ David J. Anderson, ${ }^{3}$ and H. Richard Koerber ${ }^{1}$ \\ ${ }^{1}$ Department of Neurobiology, University of Pittsburgh, Pittsburgh, Pennsylvania 15261, ${ }^{2}$ Cell and Molecular Physiology, University of North Carolina at \\ Chapel Hill, Chapel Hill, North Carolina 27599, and 3 Division of Biology, Howard Hughes Medical Institute, California Institute of Technology, Pasadena, \\ California 91125
}

The Mas-related G protein-coupled receptor D (Mrgprd) is selectively expressed in nonpeptidergic nociceptors that innervate the outer layers of mammalian skin. The function of Mrgprd in nociceptive neurons and the physiologically relevant somatosensory stimuli that activate Mrgprd-expressing $\left(\mathrm{Mrgprd}^{+}\right)$neurons are currently unknown. To address these issues, we studied three Mrgprd knock-in mouse lines using an ex vivo somatosensory preparation to examine the role of the Mrgprd receptor and Mrgprd ${ }^{+}$afferents in cutaneous somatosensation. In mouse hairy skin, Mrgprd, as marked by expression of green fluorescent protein reporters, was expressed predominantly in the population of nonpeptidergic, TRPV1-negative, C-polymodal nociceptors. In mice lacking Mrgprd, this population of nociceptors exhibited decreased sensitivity to cold, heat, and mechanical stimuli. Additionally, in vitro patch-clamp studies were performed on cultured dorsal root ganglion neurons from $\mathrm{Mrgprd}^{-/}$and $\mathrm{Mrgprd}^{+/-}$mice. These studies revealed a higher rheobase in neurons from $\mathrm{Mrgprd}^{-/-}$mice than from $\mathrm{Mrgprd}^{+/-}$mice. Furthermore, the application of the Mrgprd ligand $\beta$-alanine significantly reduced the rheobase and increased the firing rate in neurons from $\mathrm{Mrgprd}^{+/}$mice but was without effect in neurons from $\mathrm{Mrgprd}^{-/-}$ mice. Our results demonstrate that Mrgprd influences the excitability of polymodal nonpeptidergic nociceptors to mechanical and thermal stimuli.

\section{Introduction}

Numerous studies have explored the rich physiological diversity of sensory neurons that innervate cutaneous tissues. Of particular interest, the nociceptive fibers that detect pain have multiple specializations, responding to noxious chemical, thermal, or mechanical stimuli or combinations of these stimuli (Darian-Smith, 1984a,b; Perl, 1984, 1992; Koerber et al., 1988; Price, 1988; Meyer et al., 1994; Koltzenburg et al., 1997; Lawson, 2002). These nociceptive fibers are also neurochemically diverse, with widely overlapping expression patterns of histochemical markers, including ion channels, growth factor receptors, proinflammatory neuropeptides, and other signaling molecules.

One family of signaling molecules, the Mas-related $\mathrm{G}$ proteincoupled receptors (Mrgprs) (otherwise known as sensory neuron-specific receptors, or SNSRs), are predominantly expressed in small-diameter sensory neurons of the trigeminal ganglia and dorsal root ganglia (DRGs) (Dong et al., 2001; Lembo et

Received March 4, 2009; revised April 28, 2009; accepted May 18, 2009.

This work was supported by National Institutes of Health Grants R01 NS23275 and NS052848 (H.R.K) and P01 NS048499-05 (D.J.A.) and the Sloan Foundation, the Searle Scholars Program, the Klingenstein Foundation, the Whitehall Foundation, the Rita Allen Foundation, and National Institute of Neurological Disorders and Stroke Grant R01 NS060725 (all to M.J.Z.). M.J.Z. is a Rita Allen Foundation Milton E. Cassel Scholar. We sincerely thank Collene Anderson and Weiwen Wang for their excellent technical assistance and Liching Lo for assistance in making the Mrgprd-CRE knock-in mouse.

Correspondence should be addressed to H. Richard Koerber, Department of Neurobiology, W1413 BSTWR, University of Pittsburgh, Pittsburgh, PA 15261. E-mail: rkoerber@pitt.edu.

D0I:10.1523/JNEUROSCI.1057-09.2009

Copyright $\odot 2009$ Society for Neuroscience $\quad$ 0270-6474/09/298612-08\$15.00/0 al., 2002; Zylka et al., 2003). In the DRG, one member of this large family of receptors, Mrgprd (also known as MrgD, Gm499, and TGR7) (Zhang et al., 2005), is activated by $\beta$-alanine (Shinohara et al., 2004) and has been found to inhibit KCNQ/M-type potassium channels and increase excitability of sensory neurons (Crozier et al., 2007). Mrgprd is expressed in unmyelinated sensory afferents that bind isolectin-B4 (IB4) and express the ectonucleotidase prostatic acid phosphatase (previously known as fluoride resistant acid phosphatase) as well as the ATP-gated ion channel $\mathrm{P}_{2} \mathrm{X}_{3}$. Mrgprd is not extensively coexpressed with substance $\mathrm{P}$ (SP), calcitonin gene-related peptide (CGRP), or the capsaicin-, heat-, and proton-activated ion channel transient receptor potential vanilloid receptor-1 (TRPV1) (Dong et al., 2001; Zylka et al., 2003, 2005, 2008). These Mrgprd-expressing fibers have been shown recently to specifically innervate the stratum granulosum of the epidermis (Zylka et al., 2005), in which they may indirectly transduce sensation via the release of ATP from keratinocytes (Dussor et al., 2008). Currently, it is not known what physiologically relevant somatosensory stimuli activate Mrgprd ${ }^{+}$neurons. Moreover, the role that Mrgprd receptor activation plays in the overall function of these afferents is unknown.

In this study, we identified and characterized the population of sensory afferents that express Mrgprd using sharp electrode electrophysiology and an ex vivo skin/nerve/DRG/spinal cord preparation. We found that Mrgprd-expressing $\left(\mathrm{Mrgprd}^{+}\right)$neurons were polymodal in function, responding to mechanical and heat stimuli, as well as to cold stimuli in some cases. Deletion of Mrgprd resulted in a significantly reduced excitability in these 
A.

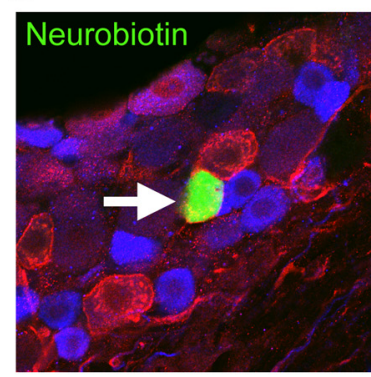

B.

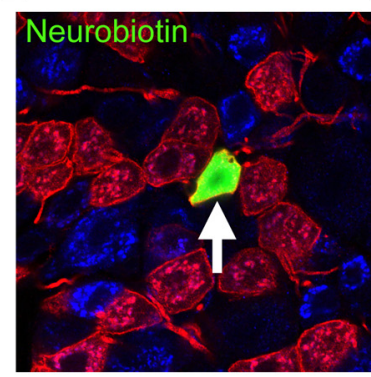

C.

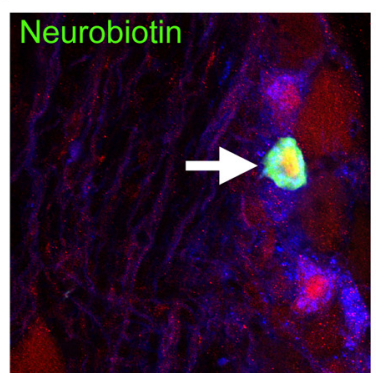

Mrgprd +/+
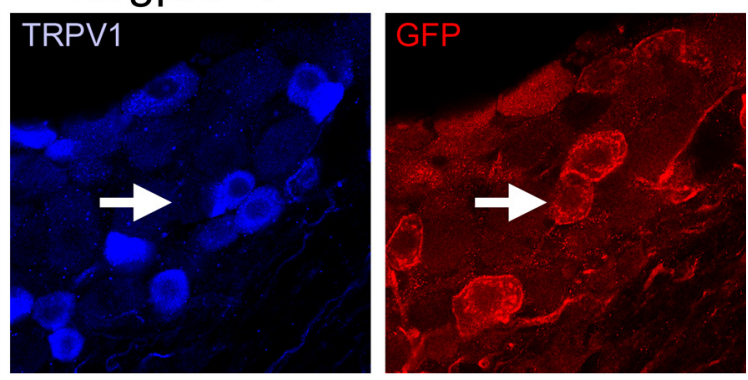

Mrgprd -/- (EGFPf)

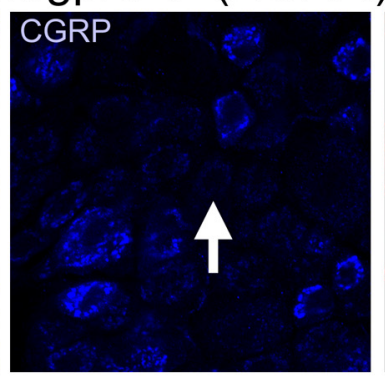

Mrgprd -/- (Cre)

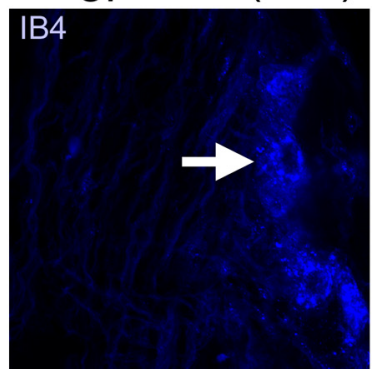

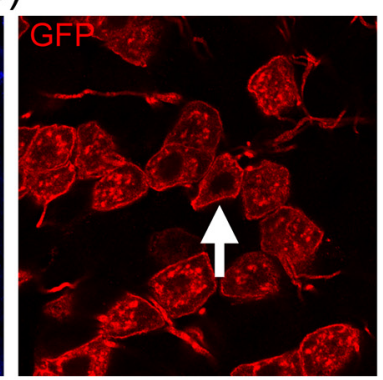

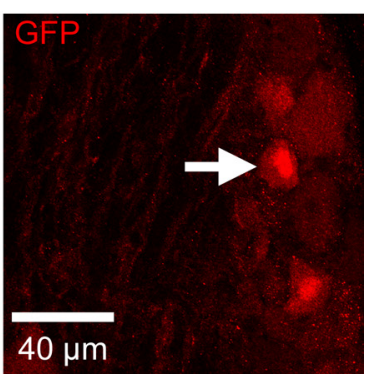

Figure 1. CPMs in Mrgprd knock-in and WT mice bind IB4 but do not express either TRPV1 or CGRP. A-C, Sample immunohistochemistry of recorded CPM cells in $\operatorname{Mrgpr}^{+/+}(\boldsymbol{A}), \operatorname{Mrgprd}^{-/-}$(EGFPf) (B), and Mrgprd ${ }^{-/-}(\mathbf{C r e})(\boldsymbol{C})$, as indicated by biotin labeling (left panels, green). Labeling of TRPV1, CGRP, and IB4 are shown for Mrgprd-IRES-EGFPf ${ }^{+/+}$, Mrgprd $^{-/-}$(EGFPf), and Mrgprd $^{-/-}$(Cre), respectively (middle panels, blue). GFP labeling is shown in the right panels (red). Arrows indicate recorded cell. Scale bar, $40 \mu \mathrm{m}$.

sensory afferents, which consisted of a decreased sensitivity to thermal and mechanical stimuli.

To further characterize the biophysical properties of Mrgprdcontaining cells, we also used dissociated patch-clamp electrophysiology to record from Mrgprd heterozygous $(+/-)$ and homozygous $(-/-)$ mouse DRG neurons in culture. We found that Mrgprd acts as a modulator of cell excitability, in which the threshold for firing a single action potential (AP) is lower in heterozygous cells than in homozygous cells. Furthermore, we show that Mrgprd is directly activated by $\beta$-alanine in DRG neurons, because $\beta$-alanine reduces the AP threshold and increases the AP firing rate in neurons from heterozygous but not homozygous mice.

\section{Materials and Methods}

All procedures used in these experiments were reviewed and approved by the Institutional Care and Use Committees at the University of Pittsburgh, University of North Carolina at Chapel Hill, and California Institute of Technology and followed the guidelines of the International Association for the Study of Pain.

Knock-in mouse lines. Mrgprd ${ }^{+/+}$gene-conserving mice contain the intact Mrgprd gene followed by internal ribosomal entry site (IRES)-farnesylated enhanced green fluorescent protein (EGFPf) (Zylka et al., 2005) (Fig.

1A). Two different Mrgprd $^{-1-}$ gene-deleting mice were also examined. In one knock-in line, the open reading frame of Mrgprd was deleted and replaced with an in-frame fusion of EGFPf [also called Mrgprd-EGFPf ${ }^{-1}$, Mrgprd ${ }^{\text {EGFPf }}$ (previously described by Zylka et al., 2005)] (Fig. 1 A). In a second knock-in line, we subcloned the EGFPCRE-frt-PGK-Neo-frt construct (Shin and Anderson, 2005) out-of-frame with the Mrgprd start codon, using previously described Mrgprd $129 / \mathrm{SvJ}$ targeting arms, to make the gene-deleting Mrgprd-Cre ${ }^{-1-}$ mice (Fig. 1A). In this second line, amino acids $20-315$ are deleted from the 321 amino acids coding region of MRGPRD (GenBank accession number AAK91800). Homologous recombination was performed in mouse CJ7 embryonic stem (ES) cells following standard procedures. Correctly targeted ES cell clones were identified by Southern blot hybridization using probes that flanked the $5^{\prime}$ and $3^{\prime}$ arms of the targeting constructs, as well as an internal neomycin probe. Chimeric mice were produced by blastocyst injection and were mated to human $\beta$-actin FLPe deleter mice (The Jackson Laboratory) (Rodríguez et al., 2000) to remove the frt-flanked selection cassette and then were mated to C57BL/6 mice to establish the line. All knock-in lines used for this study were backcrossed to C57BL/6 mice for five or more generations. For all three lines, GFP expression faithfully marked the neurons that typically express Mrgprd.

Ex vivo preparation. The ex vivo somatosensory system preparation has been described previously in detail (Woodbury et al., 2001). Briefly, adult mice [C57BL/6 (The Jackson Laboratory) and Mrgprd knock-in mice (Mrgprd ${ }^{+/+}$, Mrgprd-EGFPf ${ }^{-1}$, and Mrgprd-Cre $\left.{ }^{-/-}\right)$] were anesthetized via an intramuscular injection of ketamine and xylazine (90 and $10 \mathrm{mg} / \mathrm{kg}$, respectively) and perfused transcardially with chilled $\left(10^{\circ} \mathrm{C}\right)$, oxygenated $\left(95 \% \mathrm{O}_{2}-5 \% \mathrm{CO}_{2}\right)$ artificial CSF (aCSF) (in mmol/L: $1.9 \mathrm{KCl}, 1.2$ $\mathrm{KH}_{2} \mathrm{PO}_{4}, 1.3 \mathrm{MgSO}_{4}, 2.4 \mathrm{CaCl}_{2}, 26.0 \mathrm{NaHCO}_{3}$, and $10.0 \mathrm{D}$-glucose), with $253.9 \mathrm{mmol} / \mathrm{L} \mathrm{su}-$ crose. Spinal cord, L1-L4 DRGs, saphenous nerve, and innervated skin were dissected free in continuity. After dissection, the preparation was transferred to a separate recording chamber containing chilled oxygenated aCSF in which the sucrose was replaced with $127.0 \mathrm{mmol} / \mathrm{L} \mathrm{NaCl}$. The skin was pinned out on a stainless steel grid located at the bath/air interface, such that the dermal surface remained perfused with the aCSF while the epidermis was exposed to the air. The platform provided stability during application of thermal and mechanical stimuli. The bath was then slowly warmed to $31^{\circ} \mathrm{C}$ before recording.

Recording and stimulation. DRG cells were impaled with quartz filament microelectrodes (impedance, $>100 \mathrm{M} \Omega$ ) containing 5\% Neurobiotin (Vector Laboratories) in $1 \mathrm{~mol} / \mathrm{L}$ potassium acetate. Electrical search stimuli were delivered through a suction electrode on the saphenous nerve to locate sensory neuron somata with a peripheral axon innervating the skin. Peripheral receptive fields (RFs) were localized with a fine paint brush, blunt glass probe, and von Frey hairs. When cells were driven by the nerve but had no mechanical RF, a thermal search was performed by applying hot $\left(\sim 52^{\circ} \mathrm{C}\right)$ and/or cold $\left(\sim 0^{\circ} \mathrm{C}\right)$ physiological saline to the skin using a $10 \mathrm{ml}$ syringe with a 20 gauge needle. If a thermal RF was located, the absence of mechanical sensitivity was confirmed by searching the identified RF using a glass probe. The response characteristics of the DRG cell were determined by applying computer-controlled mechanical and thermal stimuli. The mechanical stimulator consisted of a constant-force controller (Aurora Scientific) attached to a 1-mmdiameter plastic disc. Computer-controlled $5 \mathrm{~s}$ square waves of 5, 10, 25, 
50 , and $100 \mathrm{mN}$ were applied to the RF of the cell. Mechanical threshold was determined to be the lowest stimulus intensity of this series to elicit at least one AP within the first second of stimulus application. After mechanical stimulation, thermal stimuli were applied using a 3 $\mathrm{mm}^{2}$ contact area Peltier element (Yale University Machine Shop). The cooling stimulus was rapidly applied by the Peltier element through the thermal conduction of circulating icechilled water, which resulted in a drop in temperature from 31 to $\sim 4^{\circ} \mathrm{C}$. The temperature was then brought back up to $31^{\circ} \mathrm{C}$, and, after a $5 \mathrm{~s}$ pause, the heating stimulus was applied, consisting of a $12 \mathrm{~s}$ heat ramp from 31 to $52^{\circ} \mathrm{C}$, followed by a $5 \mathrm{~s}$ plateau at $52^{\circ}$. The stimulus then ramped back down to $31^{\circ} \mathrm{C}$ in $12 \mathrm{~s}$. The cooling and heating thermal thresholds were determined to be the temperatures at which the first AP was evoked. All responses were recorded digitally for offline analysis (Spike2 software; Cambridge Electronic Design). After physiological characterization, the cell was labeled by iontophoretically injecting Neurobiotin (two to three cells per DRG). Peripheral conduction velocity was calculated from spike latency and the distance between the stimulating and recording electrodes.

Tissue processing and analysis of recorded cells. Once a sensory neuron was characterized and filled with Neurobiotin, the DRG containing the injected cell was removed and immersion fixed (4\% paraformaldehyde in $0.1 \mathrm{~m}$ phosphate buffer for $30 \mathrm{~min}$ at $4^{\circ} \mathrm{C}$ ). Ganglia were then blocked, embedded in $10 \%$ gelatin, postfixed overnight, and cryoprotected in $20 \%$ sucrose. Frozen sections $(60 \mu \mathrm{m})$ were collected in phosphate buffer and reacted with primary antisera for GFP (chicken anti-GFP; Aves Labs), and either TRPV1 (rabbit anti-TRPV1; Calbiochem) or CGRP (rabbit anti-CGRP; Millipore Bioscience Research Reagents). In many cases, the binding of isolectin B4 from Griffonia simplicifolia was also examined (IB4-647; Invitrogen). After incubation in primary antiserum, tissue was washed and incubated in donkey anti-rabbit secondary antiserum (conjugated to cyanine 2, 3, or 5; Jackson ImmunoResearch) and reacted with fluorescently tagged avidin to label Neurobiotin-filled cells (Vector Laboratories). Distribution of fluorescent staining was determined using an Olympus confocal microscope and software (Fluoview; Olympus). Sequential scanning was done to prevent bleed-through of the different fluorophores.

DRG culture. DRG from all spinal levels were dissected from adult $\mathrm{Mrgprd}^{+/-}$and $\mathrm{Mrgprd}^{-1-}$ mice, digested with $1 \mathrm{mg} / \mathrm{ml}$ collagenase (CSL1; Worthington) and $5 \mathrm{mg} / \mathrm{ml}$ dispase (17105-041; Invitrogen) for $30 \mathrm{~min}$ and then triturated. The resulting cell suspension was filtered through a $70 \mu \mathrm{m}$ cell strainer to remove debris. Cells were plated onto glass coverslips coated with $0.1 \mathrm{mg} / \mathrm{ml}$ poly-D-lysine and $5 \mu \mathrm{g} / \mathrm{ml} \mathrm{lami-}$ nin. Cells were allowed to settle for $3 \mathrm{~h}$ in DH10 medium (1:1 DMEM/ Hams-F12, 10\% horse serum, $100 \mathrm{U} / \mathrm{ml}$ penicillin, and $100 \mu \mathrm{g} / \mathrm{ml}$ streptomycin) at $37^{\circ} \mathrm{C}, 5 \% \mathrm{CO}_{2}$. Medium was replaced with fresh $\mathrm{DH} 10$ containing $25 \mathrm{ng} / \mathrm{ml}$ glial cell line-derived neurotrophic factor and 50 $\mathrm{ng} / \mathrm{ml} \mathrm{NGF}$, and cells were cultured for $1-2 \mathrm{~d}$ at $37^{\circ} \mathrm{C}, 5 \% \mathrm{CO}_{2}$.

Patch-clamp electrophysiology. $\mathrm{GFP}^{+}$neurons were visualized using epifluorescence microscopy (Nikon Eclipse FN1, NIR Apo 40×/0.80 W water-immersion objective) and recorded using whole-cell patch-clamp electrophysiology as described previously (Campagnola et al., 2008). Briefly, patch-clamp equipment (Multiclamp 700B and Digidata 1440A) and software (pClamp10) were from Molecular Devices. DRG neurons were perfused during recording in oxygenated $\left(95 \% \mathrm{O}_{2}, 5 \% \mathrm{CO}_{2}\right)$ bath solution consisting of the following (in mM): $10 \mathrm{HEPES}, 140 \mathrm{NaCl}, 4 \mathrm{KCl}$, $2 \mathrm{MgCl}_{2}, 2 \mathrm{CaCl}_{2}$, and 5 glucose, $\mathrm{pH} 7.5$ (300 mOsm). Pipette solution for DRG neurons contained the following (in mM): 10 HEPES, $135 \mathrm{KCl}, 3$ Mg-ATP, $0.5 \mathrm{Na}_{2}$-ATP, 2 EGTA, $1.1 \mathrm{CaCl}_{2}$, and 5 glucose, pH 7.5 (300 $\mathrm{mOsm})$. Patch pipettes were made of borosilicate glass and had a resistance of 3-6 M $\Omega$ when filled with pipette solution. Experiments were performed at room temperature $\left(21-24^{\circ} \mathrm{C}\right)$. Threshold current was defined as the amount of current ( $1 \mathrm{~s}$ duration) required to generate one AP before drug addition. $\beta$-Alanine ( $1 \mathrm{~mm}$; Sigma) was bath applied for 5 min, and then threshold current was injected for $1 \mathrm{~s}$ to measure changes in firing rate.

Data analysis. Because there were no significant differences observed in the biophysical, mechanical, thermal, or immunocytochemical characteristics between the cell types recorded from the two genedeleting lines of Mrgprd ${ }^{-1-}$ mice (Mrgprd-EGFPf ${ }^{-1-}$ and Mrgprd$\left.\mathrm{Cre}^{-/-}\right)$, data from these two lines were combined for analysis. Additionally, the analysis of knock-in mouse data $\left(\mathrm{Mrgprd}^{+/+}, \mathrm{Mrg}_{-}\right.$ $\mathrm{prd}^{+/-}$, and $\mathrm{Mrgprd}^{-1-}$ ) was limited to those C-polymodal nociceptor $(\mathrm{CPM})$ cells that were $\mathrm{GFP}^{+}$, thereby indicating a cell with the capacity to express Mrgprd (note that these cells are referred to as $\mathrm{Mrgprd}^{+}$neurons throughout the text and that Mrgprd ${ }^{+}$neurons from the $\mathrm{Mrgprd}^{-/-}$mice do not contain functional copies of Mrgprd), whereas analysis of wild-type (WT) data consisted of all CPM cells recorded. Consequently, the latter group undoubtedly includes some $\mathrm{Mrgprd}^{-}$cells. Data are expressed as means \pm SE. Student's $t$ tests, ANOVA, and post hoc tests were used to analyze different aspects of the ex vivo responses of neurons to electrical, mechanical, and thermal stimuli and the in vitro responses to electrical stimuli and drug application. Heat data were normalized by multiplying the average AP spikes per degree by the percentage of cells responding at that temperature.

\section{Results}

\section{Classification and distribution of cutaneous sensory neurons}

In these studies, neurons were sorted into subgroups depending on their conduction velocities (CVs) and responses to mechanical and thermal stimuli. Neurons with a conduction velocity of $<1.2 \mathrm{~m} / \mathrm{s}$ were classified as C-fibers, and all others were classified as A-fibers (presumably myelinated) (Kress et al., 1992; Koltzenburg et al., 1997).

Although we recorded from both A-fibers and C-fibers, strong evidence suggests that Mrgprd-containing afferents are C-fibers (Zylka et al., 2005). Therefore, it should be noted that we only examined enough A-fibers to verify that there were no differences in their response properties (data not shown). We also recorded from a number of cells that were driven by the peripheral stimulating electrode but were found to be both mechanically and thermally unresponsive; however, only cells that had a receptive field were included for analysis.

C-fibers were divided into six subclasses (Table 1): (1) fibers that responded to mechanical and heat $(\mathrm{CMH}),(2)$ fibers that responded to mechanical, heat, and cool/cold stimuli (CMHC), (3) C-mechanical fibers that responded to mechanical but not to thermal stimuli, (4) C-mechanical cool/cold fibers that responded to mechanical and cooling but not heating, (5) C-heat fibers that responded to heat stimuli but were mechanically insensitive, and (6) C-cooling/cold fibers that responded to decreasing skin temperature but not to heat or mechanical stimuli.

A total of 284 C-fibers innervating hindlimb hairy skin via the saphenous nerve were intracellularly recorded and physiologi- 


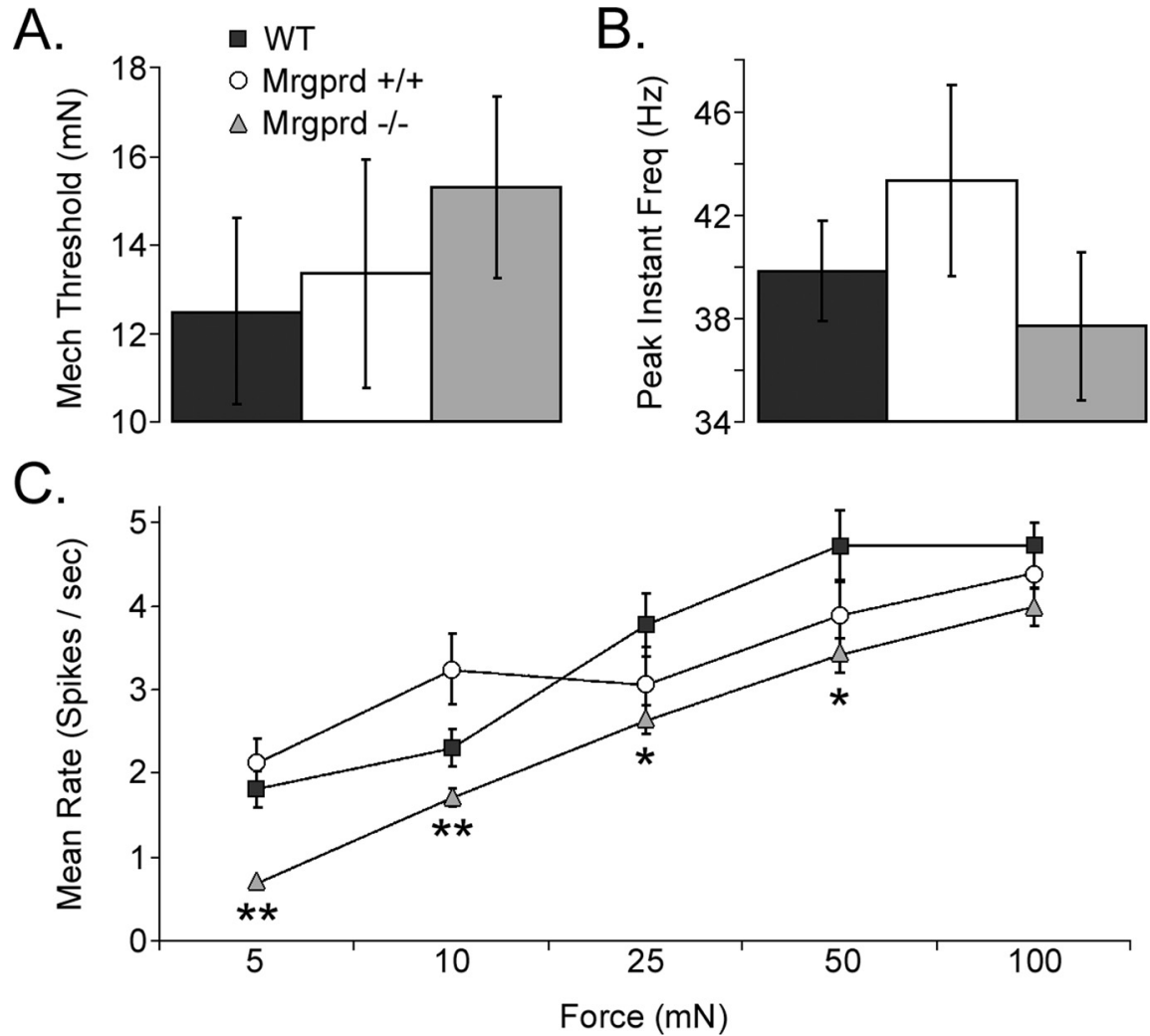

Figure 2. CPMs in $\mathrm{Mrgprd}^{-/-}$mice exhibit decreased mechanical sensitivity. Sharp electrode recordings were made from WT ${\text { (black), } \text { Mrgprd }^{+/+} \text {(white), and Mrgprd }}^{-/-}$(gray) CPM cells that were tested for their response to mechanical stimuli. $A-C$, No significant difference was observed between the mice in either the average mechanical threshold ( $\boldsymbol{A}$; millinewtons) or in the mean peak instantaneous frequency ( $\boldsymbol{B}$; hertz); however, the mean rate for multiple force stimuli ( $\boldsymbol{C}$; spikes per second; $5,10,25,50$, and $100 \mathrm{mN}$ ) were decreased in the Mrgprd ${ }^{-/}$mice. Significance $(p<0.05)$ is indicated below Mrgprd $^{-/-}$in relation to either just WT $\left({ }^{*}\right)$ or to both WT and $\operatorname{Mrgprd}^{+/+}\left(^{* *}\right)$.

cally characterized from $19 \mathrm{WT}$ ( $n=118$ cells $), 9 \mathrm{Mrgprd}^{+/+}(n=$ 45 cells $)$, and $28 \mathrm{Mrgprd}^{-1-}(n=121$ cells $)$ male mice. The distribution of these fibers across all six classes of C-fibers is shown in Table 1. Similar percentages of fibers were encountered in WT, Mrgprd $^{+/+}$, and Mrgprd ${ }^{-/-}$mice.

Apart from the cold response in CMHC cells, there was no statistical difference between the $\mathrm{CMH}$ and $\mathrm{CMCH}$ groups for any of the mouse lines, and therefore these populations were pooled together as CPM cells. As for the other C-fiber groups, no notable differences in AP features and mechanical and/or thermal response characteristics were observed (data not shown).

\section{Immunocytochemical analysis of CPMs}

We identified Mrgprd ${ }^{+}$neurons after ex vivo recordings by labeling DRG sections with antibodies against Neurobiotin and GFP. It should be noted that not all of the cells recorded in this study were stained with Neurobiotin for technical reasons. A total of 21 and 60 CPM cells from $\mathrm{Mrgprd}^{+/+}$and $\mathrm{Mrgprd}^{-/-}$knock-in mice, respectively, were recorded and labeled with Neurobiotin. Of those cells, the subsequent description of results applies to only $16 \mathrm{Mrgprd}^{+/+}$cells and $55 \mathrm{Mrgprd}^{-/-}$cells that were confirmed to be $\mathrm{GFP}^{+}$(Fig. 1). A total of 79 WT cells were also recorded, and 28 of these were labeled with Neurobiotin. Although all 79 WT cells were used for the biophysical, mechanical, and thermal analysis, it should be noted that not all of these CPM cells will have contained Mrgprd, and therefore cells from $\mathrm{Mrg}$ $\mathrm{prd}^{+/+}$mice are a more appropriate means for comparison.

In addition to verifying the presence of Neurobiotin and, in the case of the knock-in mice, GFP, immunocytochemical analysis indicates that the CPMs of $\mathrm{Mrgprd}^{-1-}$ mice express similar patterns of immunocytochemical markers as those contained in WT and Mrgprd ${ }^{+/+}$ mice (Fig. 1). We found that most Neurobiotin-filled WT CPMs bound IB4 (18 of 23; cells positive/total cells examined) but did not express either TRPV1 (0 of 22) or CGRP ( 1 of 6 ). Most $\mathrm{GFP}^{+}$and Neurobiotin-labeled CPM cells bound IB4 (Mrgprd $^{+/+}$, untested; Mrgprd ${ }^{-/-}, 32$ of 32) but did not express TRPV1 ( $\mathrm{Mrg}$ prd $^{+/+}, 0$ of 16; Mrgprd $^{-/-}, 0$ of 3 ) or CGRP (Mrgprd ${ }^{+/+}$, untested; Mrgprd ${ }^{-/-}$, 0 of 17) (Fig. 1), consistent with previous studies (Zylka et al., 2005).

Biophysical characteristics of CPM cells Before immunocytochemistry, electrophysiological recordings were made from the CPM cells. With the recording electrode penetrating a DRG cell, search stimuli were pulsed from a suction electrode on the distal portion of the intact saphenous nerve just before it enters the skin. Action potentials were consequently evoked in cells whose axonal connection to the soma was intact. This provided multiple biophysical measurements for each of these cells, including membrane potential, halfamplitude width, and CV (calculated as the distance between the stimulating and recording electrodes, divided by the spike latency between the stimulus pulse and the triggered AP). No significant differences were observed in the characteristics for any of the mouse lines (data not shown).

\section{CPMs in $\mathrm{Mrgprd}^{-/-}$mice exhibit decreased sensitivity to mechanical stimuli}

After it was determined that a cell could be driven peripherally, the search stimulus was turned off, and the peripheral RF of the CPM was isolated by brush, blunt glass probe, and von Frey hairs. CPM cells with identified RFs were then tested for their response to a computer-controlled mechanical device that applied 5, 10, 25, 50, and $100 \mathrm{mN}$ stimuli. We observed that the average mechanical threshold was not significantly different between WT $(12.49 \pm 2.10$ $\mathrm{mN})$, Mrgprd $^{+/+}(13.33 \pm 2.57 \mathrm{mN})$, and Mrgprd $^{-/-}(15.28 \pm 2.04$ $\mathrm{mN}$ ) (Fig. 2B). Similarly, the peak instantaneous frequency remained unchanged (WT, $39.82 \pm 1.91 \mathrm{~Hz} ;$ Mrgprd $^{+/+}, 43.32 \pm 3.71$ $\mathrm{Hz}$; and $\mathrm{Mrgprd}^{-/-}, 37.69 \pm 2.87 \mathrm{~Hz}$ ) (Fig. 2C). However, the mean firing rates for each of the stimuli was reduced in $\mathrm{Mrgprd}^{-/-}$mice versus WT and $\mathrm{Mrgprd}^{+/+}$mice (Student's $t$ test, $p<0.05$; verified with ANOVA and Holm-Sidak post hoc tests) (Fig. $2 D$ ). There were no significant differences observed between WT and $\mathrm{Mrgprd}^{+/+}$ mice.

\section{CPMs in Mrgprd ${ }^{-1-}$ mice have decreased cold and heat sensitivity}

After examining the mechanical response of CPM cells, a small Peltier device was used to test for thermal response characteristics. In CPM cells that responded to cooling stimuli, the average cold threshold in $\mathrm{Mrgprd}^{+/+}$mice was higher than those found in $\mathrm{Mrgprd}^{-/-}$ 
mice (Fig. 3A). From a baseline body temperature that was maintained at $31.0^{\circ} \mathrm{C}$, a rapid decrease in temperature to $\sim 4^{\circ} \mathrm{C}$ resulted in action potentials that were evoked at relatively higher temperatures in WT $\left(19.2 \pm 1.2^{\circ} \mathrm{C}\right)$ and Mrgprd $^{+/+}(22.7 \pm$ $\left.4.8^{\circ} \mathrm{C}\right)$ than those in Mrgprd $^{-/}(13.4 \pm$ $1.3^{\circ} \mathrm{C}$; Student's $t$ test, $p<0.05$; verified with ANOVA and Holm-Sidak post hoc tests) (Fig. 3A). Maximum instantaneous frequency during cooling, however, was not significantly different between the mouse lines (WT, $2.23 \pm 1.35 \mathrm{~Hz} ;$ Mrgprd $^{+/+}$, $1.72 \pm 0.45 \mathrm{~Hz}$; and Mrgprd $^{-/-}, 1.48 \pm 0.26$ $\mathrm{Hz}$ ) (Fig. 3B). For both hot and cold stimuli, no significant differences were observed between WT and $\mathrm{Mrgprd}^{+/+}$mice.

During heating ramps from 31.0 to $52.0^{\circ} \mathrm{C}$, CPMs in WT $\left(40.8 \pm 0.6^{\circ} \mathrm{C}\right)$ and $\mathrm{Mrgprd}^{+/+}\left(39.0 \pm 1.6^{\circ} \mathrm{C}\right)$ exhibited lower heat thresholds versus $\mathrm{Mrgprd}^{-/-}$(42.4 \pm $0.7^{\circ} \mathrm{C}$; Student's $t$ test, $p<0.05$; verified with ANOVA) (Fig. 4A). Similarly, maximum instantaneous frequency during heating was significantly lower in $\mathrm{Mrgprd}^{-/}$(4.88 \pm $0.67 \mathrm{~Hz})$ versus WT $(17.78 \pm 2.62 \mathrm{~Hz})$ and Mrgprd $^{+/+}(15.66 \pm 4.28 \mathrm{~Hz}$; Student's $t$ test, $p<0.05$; verified with ANOVA and Dunn's method post hoc tests) (Fig. 4B). The maximal firing rate per degree was also notably higher in WT $\left(5.2 \pm 0.4\right.$ spikes $\left./^{\circ}\right)$ and $\operatorname{Mrgprd}^{+/+}\left(5.2 \pm 0.8\right.$ spikes $\left.^{\circ}\right)$ versus those in $\mathrm{Mrgprd}^{-/-}$mice (2.8 \pm 0.7 spikes $/^{\circ}$; Student's $t$ test, $p<0.05$; verified with ANOVA and Holm-Sidak post hoc tests; data not shown). In addition, mean firing rates per degree $\left(44-52^{\circ} \mathrm{C}\right.$; Student's $t$ test, $p<0.05$; verified with ANOVA and Holm-Sidak post hoc tests) were significantly higher in WT and $\mathrm{Mrgprd}^{+/+}$than in Mrgprd ${ }^{-/-}$mice (Fig. 4C).

It should be noted that, in a related study (A. I. Basbaum, personal communication), constitutive Mrgprd ${ }^{-/-}$mice did not exhibit any mechanical or thermal behavioral phenotype. This suggests that the decrease in neuronal excitability seen here is compensated for during development by other populations of neurons, including both sensory neurons as well as spinal circuits.

\section{CPMs in Mrgprd $^{-1-}$ mice have} decreased excitability in vitro

In addition to examining the knock-in mice using the ex vivo electrophysiological technique, we also examined the excitability of $\mathrm{GFP}^{+}$cells using an in vitro electrophysiological method. Patchclamp studies revealed a higher rheobase in $\mathrm{Mrgprd}^{-/-}$mice (183.5 $\mathrm{pA} ; n=20)$ than in Mrgprd $^{+/-}$mice (103.5 pA; $n=20$; Student's $t$ test, $p<0.05)$. When using threshold current injections, the application of $\beta$-alanine reduced the rheobase in $\mathrm{Mrgprd}^{+/-}$mice to 70.0 $\mathrm{pA}$ and increased the firing rate by 3.03-fold (Student's $t$ test, $p<$ 0.05 ). In contrast, $\beta$-alanine had no effects in $\mathrm{Mrgprd}^{-/}$mice (Fig. Mrgprd $^{+/+}$mice. ${ }^{*} p<0.05$.
B.

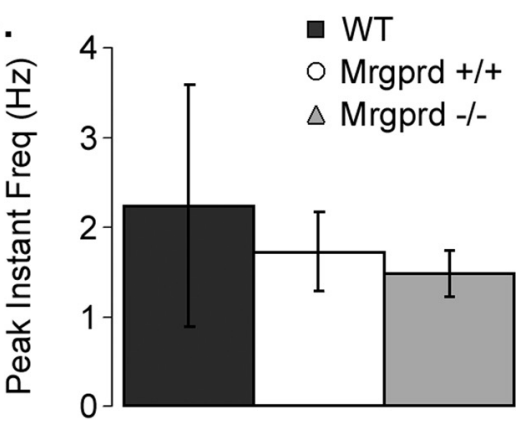

Figure 3. CPMs in Mrgprd ${ }^{-/-}$mice exhibit decreased cold sensitivity. Sharp electrode recordings were made from WT (black), Mrgprd $^{+/+}$(white), and Mrgprd ${ }^{-/-}$(gray) CPM cells that were tested for their response to cold stimuli. Mrgprd ${ }^{-1-}$ CPM cells had lower cold thresholds ( $\boldsymbol{A}$; degrees (elsius) but maintained a similar peak instantaneous frequency ( $\boldsymbol{B}$; hertz) compared with
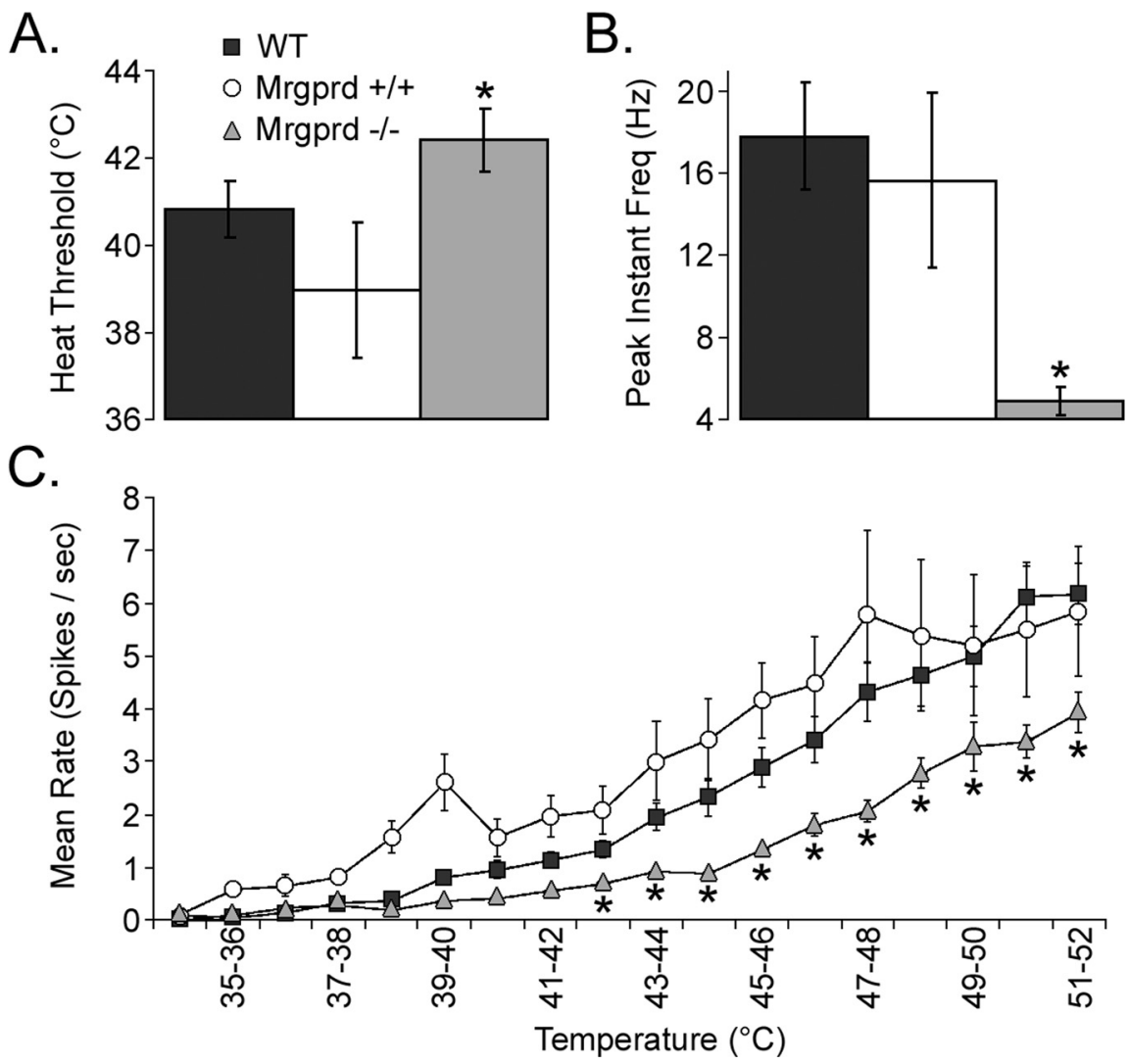

Figure 4. (PMs in Mrgprd ${ }^{-/-}$mice exhibit decreased heat sensitivity. Sharp electrode recordings were made from WT (black), Mrgprd $^{+/+}$(white), and Mrgprd ${ }^{-/-}$(gray) CPM cells that were tested for their response to heat stimuli. A, B, Compared with WT and $\mathrm{Mrgprd}^{+/+}$strains, the average thermal threshold of CPMs in $\mathrm{Mrgprd}^{-/-}$mice showed decreased excitability in terms of a higher heat threshold ( $\boldsymbol{A}$; degrees (elsius) and a lower peak instantaneous frequency ( $\boldsymbol{B}$; hertz). $\boldsymbol{C}$, A heat ramp from 31 to $52^{\circ} \mathrm{C}$ showed a significant reduction in the average spikes per second in $\mathrm{Mrgprd}^{-1-}$ mice between the temperatures of 43 and $52^{\circ} \mathrm{C}$. Significance $\left({ }^{*} p<0.05\right)$ is indicated below Mrgprd $^{-/-}$in relation to both WT and Mrgprd $^{+/+}$.

5; Table 2). There were no other significant differences between genotypes (e.g., $C_{\mathrm{m}}, R_{\mathrm{in}}$, membrane potential, and cell diameter).

\section{Discussion}

This study examined the function of Mrgprd-containing sensory afferents and the role of Mrgprd as a modulator of cell excitability. Using an ex vivo preparation, we assessed the functional role of Mrgprd in cutaneous sensory neurons by examining three knock-in mouse lines and comparing them with WT (C57BL/6) mice. Based on GFP and Neurobiotin colabeling of recorded 
Control
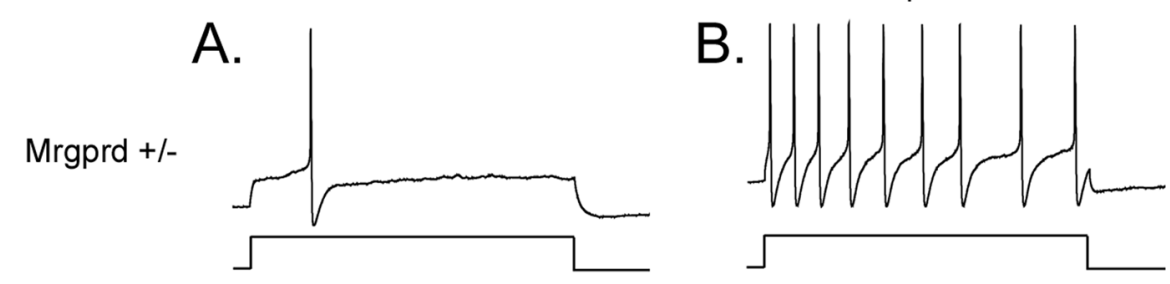

Mrgprd -l- C.

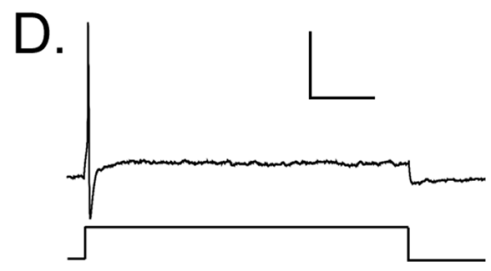

Figure 5. $\quad \beta$-Alanine increases the firing rate of $\mathrm{Mrgprd}^{+/-}$but not $\mathrm{Mrgprd}^{-/-}$DRG neurons. A-D, Whole-cell patch-clamp recordings were made from cultured GFP ${ }^{+}$DRG neurons from $\operatorname{Mrgprd}^{+/-}(A, B)$ and $\operatorname{Mrgprd}^{-1-}(C, D)$ mice. $A, C$, The threshold current ( $1 \mathrm{~s}$ pulse duration; bottom trace) required to evoke one AP (top trace) was identified for each neuron. $\boldsymbol{B}, \boldsymbol{D}, \beta$-Alanine (1 $\mathrm{mm}$ ) was then bath applied for $5 \mathrm{~min}$, and the same amount of threshold current was injected into each neuron. $\boldsymbol{B}$, Neurons expressing one functional copy of Mrgprd increased their firing rate, whereas firing rate was not increased in $\mathrm{Mrgprd}^{-/-}$neurons (D). $\boldsymbol{A}-\boldsymbol{D}$, In these cells, the threshold current was $100 \mathrm{pA}$. Calibration: $40 \mathrm{mV}, 200 \mathrm{~ms}$.

Table 2. Deletion of $M r g p r d$ reduces DRG neuron excitability and abolishes sensitivity to $1 \mathrm{~mm} \boldsymbol{\beta}$-alanine

\begin{tabular}{|c|c|c|c|c|c|c|}
\hline \multirow[b]{2}{*}{ Genotype } & \multicolumn{3}{|l|}{$I_{\text {th }}(\mathrm{pA})$} & \multicolumn{3}{|l|}{ APs at $I_{\text {th }}$} \\
\hline & Control & $\beta$-Alanine & $p$ value & Control & $\beta$-Alanine & $p$ value \\
\hline$+1-$ & $103.5 \pm 17.4$ & $70 \pm 10.0$ & 0.006 & $1.1 \pm 0.1$ & $3.2 \pm 0.5$ & 0.0002 \\
\hline$-1-$ & $183.5 \pm 27.9$ & $196 \pm 29.3$ & N.S. & $1.1 \pm 0.1$ & $0.9 \pm 0.2$ & N.S. \\
\hline
\end{tabular}

$I_{\text {th }}$ Threshold current to generate one AP, determined using whole-cell patch-clamp electrophysiology; $n=20 \mathrm{GFP}^{+}$neurons per genotype. Data are presented as means \pm SEM. $p$ values from paired $t$ test are shown. N.S., Not significant $(p>0.05)$.

cells, we found that the Mrgprd receptor was almost exclusively localized in a large subset of CPMs that respond to mechanical stimuli, as well as to heat and sometimes cold stimuli. In the transgenic animals that we examined in this study, 76 and $92 \%$ of the CPM cells recorded from $\mathrm{Mrgprd}{ }^{+/+}$and $\mathrm{Mrgprd}^{-/-}$strains, respectively, exhibit expression of GFP driven by the Mrgprd promoter. The disparity in percentages could reflect the fact that, in $\mathrm{Mrgprd}^{+/+}$cells, EGFP (the surrogate marker for Mrgprd expression) is expressed after an IRES, whereas in $\mathrm{Mrgprd}^{-1-}$ cells, it is inserted as part of the coding sequence. Based on unpublished observations (M. J. Zylka and D. J. Anderson), the level of EGFP expression in the former line is $\sim 10$-fold lower than in the latter line. So the value of $76 \%$ could be an underestimate because of the lower expression of EGFP.

Deletion of Mrgprd significantly decreased sensitivity to mechanical and thermal stimuli. Specifically, a decreased firing rate was observed in cells lacking Mrgprd in response to lower mechanical forces and noxious heat. Additionally, thresholds of activation were remarkably lower in response to cold and higher in response to hot stimuli. The decreased firing rates in response to mechanical and thermal stimuli, as well as the greater deviation from normal body temperatures that was required for CPMs to start firing suggests that Mrgprd may be necessary to maintain normal excitability. In support of this, in vitro patch-clamp studies on cultured DRG neurons from mice lacking Mrgprd had a higher rheobase than heterozygous mice. The application of a known Mrgprd ligand, $\beta$-alanine, significantly reduced the rheobase and increased the firing rate in the neurons of heterozygous mice but not in $\mathrm{Mrgprd}^{-/-}$mice.
Sensory neurons that express the Mrgprd receptor share multiple characteristics of unmyelinated nociceptors. Immunohistochemically, these afferents bind IB4 and express $\mathrm{P}_{2} \mathrm{X}_{3}$ but not SP, CGRP, or TRPV1 (Dong et al., 2001; Zylka et al., 2003, 2005). Similarly, in this study as well as in previous studies in our laboratory using $\mathrm{C} 57 \mathrm{BL} / 6$, Swiss Webster, and $\mathrm{C} 3 \mathrm{H} /$ BL6 WT mice, the vast majority of CPM fibers innervating mouse hairy skin characteristically bind IB4 and express $\mathrm{P} 2 \mathrm{X}_{3}$, rarely express CGRP, but always lack TRPV1 (Albers et al., 2006; Lawson et al., 2008). Additionally, patch clamp of dissociated mouse DRG by Dussor et al. (2008) indicated that $\mathrm{Mrgprd}^{+}$cells have somas with small diameters, long-duration APs, TTX-resistant $\mathrm{Na}^{+}$currents, and $\mathrm{Ca}^{2+}$ currents inhibited by opioids. Finally, immunocytochemical analysis in this study confirmed that the majority of Neurobiotin-labeled CPM cells were in fact $\mathrm{GFP}^{+}$(and hence normally Mrgprd $^{+}$).

All of the CPM cells that contained Mrgprd in this study responded to cold and/or heat. It is well established that some of the key proteins involved in thermal transduction belong to the TRP family, including TRPV1 (Caterina et al., 1997), TRPV2 (Caterina et al., 1999), TRPA1 (Story et al., 2003), TRPM8 (Peier et al., 2002a), and others. Previous work from our laboratory indicates that CPM cells are the largest population of heat-responding sensory afferents found in mouse hairy skin, but they lack the heat, capsaicin, and proton-sensitive TRPV1 channel (Zwick et al., 2002; Woodbury et al., 2004; Lawson et al., 2008). Instead, this protein appears to be isolated to a small population of mechanically insensitive C-fibers that respond to heat (Lawson et al., 2008). In agreement with this data, Dussor et al. (2008) showed that dissociated cells containing Mrgprd fail to respond to either capsaicin or protons. Similarly, heat threshold and immunohistochemical evidence argue against the presence of heat-activated TRPV2 in the CPMs of WT animals (Woodbury et al., 2004; Lawson et al., 2008). As for the ionic currents evoked by cold stimuli in some $\mathrm{Mrgprd}^{+} \mathrm{CPMs}$, a previous report suggests that there is a lack of functional TRPM8 $\left(\leq 25^{\circ} \mathrm{C}\right)$ and TRPA1 $\left(\leq 17^{\circ} \mathrm{C}\right)$ as well, judging by the lack of a response to either the TRPM8 agonist menthol or the TRPA1 agonist cinnamaldehyde (Dussor et al., 2008). Thus, how these sensory afferents transduce thermal signals remains to be determined.

Although direct activation of known TRP channels by temperature seems unlikely in Mrgprd $^{+}$neurons, temperature could be sensed indirectly in $\mathrm{Mrgprd}^{+}$afferents via the release of ATP from keratinocytes (Dussor et al., 2008). Mrgprd ${ }^{+}$neurons express the ATP-gated receptor $\mathrm{P}_{2} \mathrm{X}_{3}$ (Zylka et al., 2005) and respond robustly to ATP with $\mathrm{P}_{2} \mathrm{X}_{3}$-like current kinetics (Dussor et al., 2008). In this way, changes in temperature (and perhaps other stimuli) are detected by skin cells, which then propagate signals to $\mathrm{Mrgprd}^{+}$fibers in the stratum granulosum through the release of ATP. Such a role for keratinocytes in the sensation of the external environmental stimuli has been suggested previously (for review, 
see Peier et al., 2002b; Denda et al., 2007; Lumpkin and Caterina, 2007). However, support for such a signaling mechanism is mixed. For example, $\mathrm{P}_{2} \mathrm{X}_{3}^{-1-}$ mice exhibit a reduced response of wide dynamic range neurons in the spinal cord dorsal horn to hindpaw heating (Souslova et al., 2000; Shimizu et al., 2005); however, behavioral testing indicated normal withdrawal from a hot plate and paradoxically indicated an enhanced avoidance of hot and cold temperatures in a thermal gradient (Shimizu et al., 2005). Although these findings may reflect that some form of compensatory mechanism exists, they also suggest that the mechanism of transduction is more complex than ATP release from kerotinocytes and activation of $\mathrm{P}_{2} \mathrm{X}_{3}$ receptors in this subset of nociceptive fibers.

Although we tested for mechanical and thermal responsiveness in CPM fibers, we did not test these cells for responses to chemical stimuli using the ex vivo preparation. It is likely that these Mrgprd ${ }^{+}$afferents are activated by molecules other than ATP, including the Mrgprd agonist $\beta$-alanine (Shinohara et al., 2004). In this study, using a dissociated cell preparation, we demonstrated for the first time that $\mathrm{Mrgprd}^{+}$neurons are directly sensitized by $\beta$-alanine. $\beta$-Alanine and the related dipeptide carnosine ( $\beta$-alanyl-L-histidine) are present in high concentrations in vertebrate muscles and skin (Crush 1970; Nagai et al., 1986; Kohen et al., 1988) as well as rat sciatic nerve (Marks et al., 1970). In addition, $\beta$-alanine can be generated from carnosine by carnosinase enzymes. Together, this suggests that $\beta$-alanine could be present and/or produced in skin and tonically activate Mrgprd on sensory afferents. Tonic activation of Mrgprd could in turn increase the excitability of $\mathrm{Mrgprd}^{+}$neurons via inhibition of $\mathrm{KCNQ} / \mathrm{M}$-currents (Crozier et al., 2007). The loss of this tonic activation could explain why Mrgprd ${ }^{+}$neurons are less sensitive to thermal, mechanical, cold, and electrical stimulation when the Mrgprd receptor is deleted. However, it should be noted that we have made repeated attempts, using the same the voltage step protocol used in rat sensory neurons (Crozier et al. 2007), but have been unable to reliably record M-currents in Mrgprd-GFP neurons. In addition, our colleague, Dr. Greg Dussor, has also experienced the same difficulties in recording the M-current in these cells (G. Dussor, personal communication). Therefore, we were unable to directly test this hypothesis.

Numerous studies have shown that the C-fiber population consists of multiple subsets of cells having a diverse pattern of histochemical markers, including neuropeptides, growth factor receptors, purinergic receptors, heat/cold-sensing receptors, proton-sensing receptors, IB4 binding, and others. The majority of these markers, however, are expressed in overlapping patterns in a wide range of cells types and/or tissue types. In this study, $\mathrm{Mrgprd}^{+}$neurons accounted for 76-92\% of the total CPM cells recorded from knock-in animals. Considering work done by this laboratory and by others, the overwhelming localization of Mrgprd in CPM cells of the skin and its absence in other C-fiber groups and tissue types makes Mrgprd useful for targeting a major population of nonpeptidergic C-polymodal nociceptors that innervate the skin.

The results presented in this study verify two key aspects of $\mathrm{Mrgprd}^{+}$fibers. First, this receptor is localized in sensory afferents of the skin that specifically function as C-polymodal nociceptors. Second, it directly supports the idea that Mrgprd can influence cell excitability, at least in response to mechanical and thermal stimuli, as well as to its ligand $\beta$-alanine.

\section{References}

Albers KM, Woodbury CJ, Ritter AM, Davis BM, Koerber HR (2006) Glial cell-line-derived neurotrophic factor expression in skin alters the mechanical sensitivity of cutaneous nociceptors. J Neurosci 26:2981-2990.

Campagnola L, Wang H, Zylka MJ (2008) Fiber-coupled light-emitting diode for localized photostimulation of neurons expressing channelrhodopsin-2. J Neurosci Methods 169:27-33.

Caterina MJ, Schumacher MA, Tominaga M, Rosen TA, Levine JD, Julius D (1997) The capsaicin receptor: a heat-activated ion channel in the pain pathway. Nature 389:816-824.

Caterina MJ, Rosen TA, Tominaga M, Brake AJ, Julius D (1999) A capsaicin-receptor homologue with a high threshold for noxious heat. Nature 398:436-441.

Crozier RA, Ajit SK, Kaftan EJ, Pausch MH (2007) MrgD activation inhibits $\mathrm{KCNQ} / \mathrm{M}$-currents and contributes to enhanced neuronal excitability. J Neurosci 27:4492-4496.

Crush KG (1970) Carnosine and related substances in animal tissues. Comp Biochem Physiol 34:3-30.

Darian-Smith I (1984a) The sense of touch: performance and peripheral neural processes. In: Handbook of physiology: the nervous system-sensory processes, pp 739-788. Washington, D.C.: American Physiological Society.

Darian-Smith I (1984b) Thermal sensibility. In: Handbook of physiology: the nervous system—-sensory processes, pp 879-913. Washington, D.C.: American Physiological Society.

Denda M, Nakatani M, Ikeyama K, Tsutsumi M, Denda S (2007) Epidermal keratinocytes as the forefront of the sensory system. Exp Dermatol 16:157-161.

Dong X, Han S, Zylka MJ, Simon MI, Anderson DJ (2001) A diverse family of GPCRs expressed in specific subsets of nociceptive sensory neurons. Cell 106:619-632.

Dussor G, Zylka MJ, Anderson DJ, McCleskey EW (2008) Cutaneous sensory neurons expressing the Mrgprd receptor sense extracellular ATP and are putative nociceptors. J Neurophysiol 99:1581-1589.

Koerber HR, Druzinsky RE, Mendell LM (1988) Properties of somata of spinal dorsal root ganglion cells differ according to peripheral receptor innervated. J Neurophysiol 60:1584-1596.

Kohen R, Yamamoto Y, Cundy KC, Ames BN (1988) Antioxidant activity of carnosine, homocarnosine, and anserine present in muscle and brain. Proc Natl Acad Sci U S A 85:3175-3179.

Koltzenburg M, Stucky CL, Lewin GR (1997) Receptive properties of mouse sensory neurons innervating hairy skin. J Neurophysiol 78:1841-1850.

Kress M, Koltzenburg M, Reeh PW, Handwerker HO (1992) Responsiveness and functional attributes of electrically localized terminals of cutaneous C-fibers in vivo and in vitro. J Neurophysiol 68:581-595.

Lawson JJ, McIlwrath SL, Woodbury CJ, Davis BM, Koerber HR (2008) TRPV1 unlike TRPV2 is restricted to a subset of mechanically insensitive cutaneous nociceptors responding to heat. J Pain 9:298-308.

Lawson SN (2002) Phenotype and function of somatic primary afferent nociceptive neurones with C-, Adelta- or Aalpha/beta-fibres. Exp Physiol 87:239-244.

Lembo PM, Grazzini E, Groblewski T, O’Donnell D, Roy MO, Zhang J, Hoffert C, Cao J, Schmidt R, Pelletier M, Labarre M, Gosselin M, Fortin Y, Banville D, Shen SH, Ström P, Payza K, Dray A, Walker P, Ahmad S (2002) Proenkephalin A gene products activate a new family of sensory neuron-specific GPCRs. Nat Neurosci 5:201-209.

Lumpkin EA, Caterina MJ (2007) Mechanisms of sensory transduction in the skin. Nature 445:858-865.

Marks N, Datta RK, Lajtha A (1970) Distribution of amino acids and of exoand endopeptidases along vertebrate and invertebrate nerves. J Neurochem 17:53-63.

Meyer RA, Campbell JN, Raja SN (1994) Peripheral neural mechanisms of nociception. In: Textbook of Pain (Wall PD, Melzack R, eds), pp 13-44. New York: Churchill Livingstone.

Nagai K, Suda T, Kawasaki K, Mathuura S (1986) Action of carnosine and beta-alanine on wound healing. Surgery 100:815-821.

Peier AM, Moqrich A, Hergarden AC, Reeve AJ, Andersson DA, Story GM, Earley TJ, Dragoni I, McIntyre P, Bevan S, Patapoutian A (2002a) A TRP channel that senses cold stimuli and menthol. Cell 108:705-715.

Peier AM, Reeve AJ, Andersson DA, Moqrich A, Earley TJ, Hergarden AC, Story GM, Colley S, Hogenesch JB, McIntyre P, Bevan S, Patapoutian A 
(2002b) A heat-sensitive TRP channel expressed in keratinocytes. Science 296:2046-2049.

Perl ER (1984) Pain and nociception. In: Handbook of physiology: the nervous system-sensory processes, pp 915-975. Washington, D.C.: American Physiological Society.

Perl ER (1992) Function of dorsal root ganglion neurons: an overview. In: Sensory neurons: diversity, development and plasticity (Scott SA, ed). New York: Oxford UP.

Price DD (1988) Psychological and neural mechanisms of pain. New York: Raven.

Rodríguez CI, Buchholz F, Galloway J, Sequerra R, Kasper J, Ayala R, Stewart AF, Dymecki SM (2000) High-efficiency deleter mice show that FLPe is an alternative to Cre-loxP. Nat Genet 25:139-140.

Shimizu I, Iida T, Guan Y, Zhao C, Raja SN, Jarvis MF, Cockayne DA, Caterina MJ (2005) Enhanced thermal avoidance in mice lacking the ATP receptor P2X3. Pain 116:96-108.

Shin D, Anderson DJ (2005) Isolation of arterial-specific genes by subtractive hybridization reveals molecular heterogeneity among arterial endothelial cells. Dev Dyn 233:1589-1604.

Shinohara T, Harada M, Ogi K, Maruyama M, Fujii R, Tanaka H, Fukusumi S, Komatsu H, Hosoya M, Noguchi Y, Watanabe T, Moriya T, Itoh Y, Hinuma S (2004) Identification of a $G$ protein-coupled receptor specifically responsive to beta-alanine. J Biol Chem 279:23559-23564.

Souslova V, Cesare P, Ding Y, Akopian AN, Stanfa L, Suzuki R, Carpenter K, Dickenson A, Boyce S, Hill R, Nebenuis-Oosthuizen D, Smith AJ, Kidd EJ, Wood JN (2000) Warm-coding deficits and aberrant inflammatory pain in mice lacking P2X3 receptors. Nature 407:1015-1017.
Story GM, Peier AM, Reeve AJ, Eid SR, Mosbacher J, Hricik TR, Earley TJ, Hergarden AC, Andersson DA, Hwang SW, McIntyre P, Jegla T, Bevan S, Patapoutian A (2003) ANKTM1, a TRP-like channel expressed in nociceptive neurons, is activated by cold temperatures. Cell 112:819-829.

Woodbury CJ, Ritter AM, Koerber HR (2001) Central anatomy of individual rapidly adapting low-threshold mechanoreceptors innervating the "hairy" skin of newborn mice: early maturation of hair follicle afferents. J Comp Neurol 436:304-323.

Woodbury CJ, Zwick M, Wang S, Lawson JJ, Caterina MJ, Koltzenburg M, Albers KM, Koerber HR, Davis BM (2004) Nociceptors lacking TRPV1 and TRPV2 have normal heat responses. J Neurosci 24:6410-6415.

Zhang L, Taylor N, Xie Y, Ford R, Johnson J, Paulsen JE, Bates B (2005) Cloning and expression of MRG receptors in macaque, mouse, and human. Brain Res Mol Brain Res 133:187-197.

Zwick M, Davis BM, Woodbury CJ, Burkett JN, Koerber HR, Simpson JF, Albers KM (2002) Glial cell line-derived neurotrophic factor is a survival factor for isolectin B4-positive, but not vanilloid receptor 1-positive, neurons in the mouse. J Neurosci 22:4057-4065.

Zylka MJ, Dong X, Southwell AL, Anderson DJ (2003) Atypical expansion in mice of the sensory neuron-specific Mrg G protein-coupled receptor family. Proc Natl Acad Sci U S A 100:10043-10048.

Zylka MJ, Rice FL, Anderson DJ (2005) Topographically distinct epidermal nociceptive circuits revealed by axonal tracers targeted to Mrgprd. Neuron 45:17-25.

Zylka MJ, Sowa NA, Taylor-Blake B, Twomey MA, Herrala A, Voikar V, Vihko P (2008) Prostatic acid phosphatase is an ectonucleotidase and suppresses pain by generating adenosine. Neuron 60:111-122. 